International Journal of Social Sciences and Humanities
Available online at http://sciencescholar.us/journal/index.php/ijssh
Vol.1 No. 3, December 2011, pages: 59 73
e-ISSN: 2550-7001, p-ISSN: 2550-701X
http://dx.doi.org/10.21744/ijssh.v1i3.56

\title{
Economic Impacts of Craftsman Statue on Community Based Tourism Development
}

A.A. Gde Putra Pemayun a; A.A. Istri Agung Maheswari ${ }^{\text {b }}$

Article history: Received 5 July 2017; Accepted in revised form 12 November 2017; Approved 28 November 2017; Available online 8 December 2017

\section{Correspondence Author a}

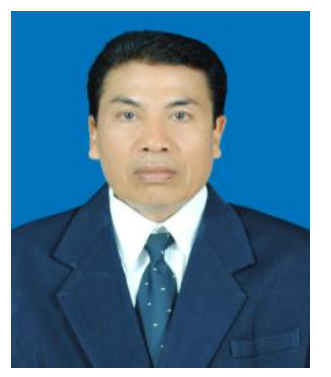

\section{Keywords}

Economic impact;

Economic system;

Community based

Tourism;

Globalization;

Human behavior;

\section{Abstract}

This study examines the "Economic Impact of Craftsmen Statue on Community Base Tourism Development in Tohpati village Klungkung Bali". The core concept of economic problems is the imbalance between unlimited human needs and the means of satisfying the needs of a limited number. Economics should not be emphasized through the point, but it should be emphasized as an approach to explain human behavior (Gary Becker). The economic system is a means used to regulate all economic activities in society whether done by the government or private in order to achieve prosperity and prosperity together. The Economic system can be divided into three namely: a First capitalist economic system that is all economic activity submitted to the market. Second, the communist economic system is all things governed by the government. The third is a mixed economic system that is a combination of the two economic systems above (capitalist and communist). Indonesia should adopt a mixed economic system because firstly, Indonesia is an emerging country, where market failures often occur due to uneven information or accessibility to transportation and communication facilities. The second is that there are still many Indonesian people are below the poverty line. Thirdly most Indonesians have businesses that are still classified into small and medium enterprises that still can not compete perfectly with a bigger business.
\end{abstract}

a Undiknas University, Denpasar, Bali-Indonesia

b Undiknas University, Denpasar, Bali-Indonesia 
e-ISSN : 2550-7001, p-ISSN : 2550-701X@ Copyright 2017. The Author. SS Journals Published by Universidad Técnica de Manabí.

This is an open-access article under the CC BY-SA 4.0 license

(https://creativecommons.org/licenses/by-sa/4.0/)

All rights reserved.

\section{Contents}

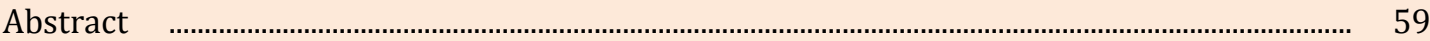

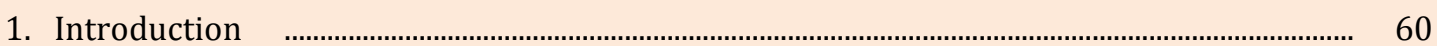

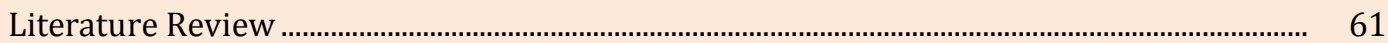

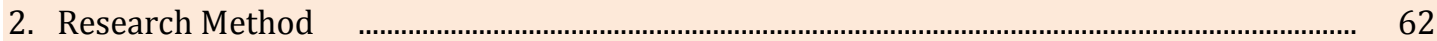

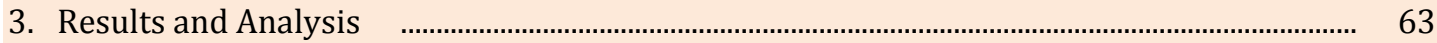

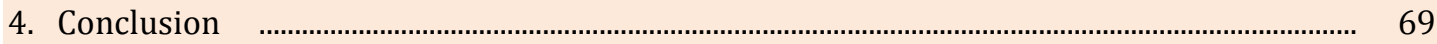

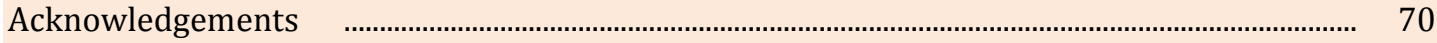

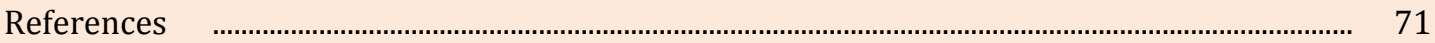

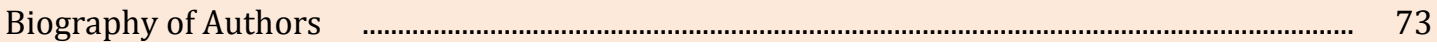

\section{Introduction}

The development of sculpture in the of Tohpati Village Klungkung Bali since a decade ago. This makes in the village of Tohpati Klungkung Bali already known as one of sculpture center in the east and south Bali area. The creativity of this sculpture artist is able to create a statue with a very creative and innovative form in accordance with today's teachings and based on various kinds of grip. A development can not be separated from the existence of a change. ${ }^{1}$ Development can mean moving from one point to another, moving and flowing with increasing currents. So development is not just changing, but change must benefit from various aspects. The development of sculpture in the village of Tohpati Klungkung was pioneered by young artist Ketut Mara who has been statue several times abroad (Japan). It is this that increasingly makes the progress of sculpture in the Tohpati village Klungkung growing. This condition is in accordance with the statement of ${ }^{2}$ which states that the arrival of tourists can excite the artistic life in Bali, especially in the village of Tohpati Klungkung Bali because with the increasing number of arrival orders both from local government and Ubud and Nusa Dua hotels, Fast economic turnaround happens. With a large number of workers accommodated in this sector will have an impact on increasing people's incomes and can reduce unemployment. The rapid development of Bali tourism led to the increasing demand for sculpture in some tourism centers so that the crafters not only create traditional statues but also work on sculpture art of tourism needs. In general, there are two types of sculpture made by the craftsmen namely, traditional sculpture and modern sculpture. The traditional sculpture is a work of sculpture which is hereditary can still show its existence with a standard grip. While the art of modern sculpture is a sculpture art that can adopt universal values in accordance with the development of science and technology. ${ }^{3}$

The growth of sculpture in the village of Tohpati Klungkung Bali is not only stalled on the development of the form but also the craftsmen have started to develop both in terms of media and engineering workmanship. Where in the first traditional sculpture is made by chiseling and takes a long time in every manufacturer? This is the obstacle when they serve tourists who always demand everything fast-paced with competitive prices. To anticipate that the artisan sculpture in the Tohpati village Klungkung Bali has developed a sculpture reproduction technique with silicone printing techniques or often called casting techniques. Through the reproduction system, the crafters are able to anticipate the problem of production process faced so far. Through casting techniques, the crafters are possible to produce a very complicated sculpture only at a certain time. In short, the production line will lower the costs and the profits will be greater so that the production of the sculpture will be able to compete in the local, national and international. 


\section{Literature Review}

The case study on sculpture artists has been extensively researched but the special research on the economic impact of sculpture craftsmen on community-based tourism is interesting to be studied because of the work of these crafters as a pilot in Klungkung. Based on research studies of sculpture artists, the results of the ${ }^{4}$ study, entitled "The Impact of Tourism on Traditional Sculpture in Silakarang village." The results of this study describe tourism bringing a very wide change of order and value in the artwork. The change is a driving force in the development, maintenance, preservation and even risk to the social and natural environment. The adaptation of local communities to tourists has a background in their interest in the Hindu worldview, customs, beliefs, and also the background of interest in the production of arts and crafts (sculpture). The focus of the study of artists is very adaptive to the ideas brought by tourists in an attempt to create a new sculpture design. Travelers also greatly appreciate traditional sculpture as a local color identity to be maintained and developed, incorporating new innovations. Understanding the acculturation of ideas with different cultures, came the creative idea, in addition, to meet local needs as well to meet the needs of tourists. Also, Ketut Sida Arsa's research (2012) entitled "Reproduction of Sculpture Through Print Techniques in Singapadu Kaler village, Sukawati, Gianyar, Bali." The results of this study explained that the sculptor in the village has started to develop both in terms of media and techniques Workmanship. In the beginning, the traditional sculpture is made by chiseling and takes a long time in every make. This is the obstacle when they serve tourists who demand everything fast-paced with competitive prices. To anticipate this the artisan's sculpture in the village of Tohpati Klungkung has developed a sculpture reproduction techniques with silicone printing techniques or often called the casting technique. Through the reproduction system, the crafters are able to anticipate the problem of production process faced so far. Through casting techniques, the crafters are possible to produce a very complicated sculpture only at a certain time. The focus of the study is about the grace period completion of sculpture orders required modern technology in the form of casting techniques, then the short flow of production will lower the cost and profit gained greater. While this research specifically takes the theme of the economic impact of sculpture artists on the development of Community-Based Tourism in the village of Tohpati Klungkung Bali with the expectations of the cultural industry in this area continues to grow as the progress of science and technology and the impact on the surrounding community.

\section{Research Method}

Types and Data Sources

The data used in this research are:

1. Primary data is data and information obtained directly from sources/respondents. This data was obtained by interviewing the artisans of sculptures in the village of Tophpati Klungkung, as a research sampling unit. The population of this study is all sculpture artists by using proportional sampling technique with a sample of 12 sculpture craftsmen.

2. Secondary data, namely data and supporting information obtained from Tohpati village Klungkung office.

\section{Research Sites}

Research location in the village of Tohpati Klungkung by observing and mapping the economic impact of sculpture craftsmen on the development of community-based tourism. The observation time as an object of analysis is the condition of 1 (one) year running in 2016. Consideration of 2016 usage is taken to facilitate recording of information to the respondent, that is, the artisans of sculpture in Tohpati Klungkung traced from the income level.

Pemayun, A., \& Maheswari, A. (2017). Economic Impacts of Craftsman Statue on Community Based Tourism Development. International Journal Of Social Sciences And Humanities (IJSSH), 1(3), 59-73. doi:10.21744/ijssh.v1i3.56 


\section{Research Instruments}

The instrument used in this research is descriptive research through literature survey and field survey and in-depth interview. The interviews were open-ended questions and closedended questions.

\section{Data Analysis Method}

The method of analysis used in this study includes several methods in accordance with the objectives of the study are as follows.

1. The Adam Smith Free Market Theory

The free market is a new world order in which the global society will be united in a common system as well as the same prosperity. Institutionally Indonesia has long agreed to various free-market agreements both bilaterally and multilaterally. This can be seen by the many international agreements on free market which can theoretically bring benefits to the countries that implement them

For the free market Bali, quantitatively has had a positive impact on various economic sectors such as the number of Foreign Investment firms standing, job opening, Gross Domestic Product increase, the inclusion of diverse and competitive consumer goods, the availability of international experts and of course the entry New cultures of congenital free markets such as patterns of consumption and lifestyle. But qualitatively, the impact of the free market on the welfare of the state and society as envisioned by Adam Smith seems not yet to be realized. Indicators show that the existence of the Multi-National Corporation is limited to the hiring of cheap labor at the operator level, the swift rush of agricultural products and small industries from many other countries has created thousands of new unemployment in agriculture, the intellectual property right that makes everything More expensive and the most frightening is the large number of emerging import substitution industries that are not the primary industries of domestic demand and pure export orientation. Most countries today are members of the World Trade Organization's multilateral trade agreement. However, most governments still impose some protectionist policies aimed at supporting local employment, such as the application of import tariffs or subsidies for exports. Economists who advocate the free trade market believe that is the reason why certain civilizations are economically prosperous. Adam Smith points to increased trade as an excuse for the development of not just Mediterranean culture such as Egypt, Greece, and Rome, but also from Bengal (East India) and China. Free trade policies have fought with mercantilism, protectionist, isolationist, communist, populist, and other policies for centuries.

2. Theory of Cultural Reproduction

Reproduction is defined as a process of cultural development by cloning breeding signs that gave birth to a form of uniformity ${ }^{5}$. Reproduction as a cultural culture process is controlled by commercial principles and capitalism ${ }^{6}$. A work of art that has been reproduced, it has become a part of everyday life as a commodity, so the work of art has lost its status to something different and separate. In other words, through the process of reproducing the creation of a work of art based solely on economic interests alone will ultimately create a mass culture. According to Benjamin the development of reproductive technology has enabled the achievement of perfect reproduction or perfect simulacru ${ }^{7}$. In this case, the sculpture in the village of Tohpati Klungkung Bali has undergone a process of reproduction where creation is based on economic interests alone. This is evident from the orientation of the use of casting techniques in the production process that is solely used only to pursue the target quantity to be achieved, to meet market demand through advances in reproduction technology art sculpture packed and mass-produced in accordance with predetermined patterns.

The process of reproduction has made the aesthetics of sculpture in the village of Tohpati Klungkung Bali to be standardized. Aesthetic commodities are aesthetics controlled by 
commercial principles and capitalism ${ }^{8}$, called Adorno and Horkheimer culture industry (culture industry). The development of technology is one source of cultural change. Technology has indirectly led people's thinking to lead to things that are lighter and easier. The change of a culture is strongly influenced by the material factor, ie technology ${ }^{9}$. In other words, cultural reproduction is an affirmation of indigenous culture to a new residence. Cultural reproduction is motivated by changes in the area of residence, social background, cultural background, which in turn will give color to the identity of the group and the identity of ethnicity ${ }^{10}$. Cultural reproduction is the meeting of two different cultures and each other affect each other so that a new culture that embodies elements of the two cultures. Marx's materialist concepts that technology can cause social change through three different ways are: First, new technology can increase the possibilities in society. A thing that is not possible in the past will be possible with the help of technology. Both new technologies change the pattern of interaction in society. Third, new technology causes new life problems for society. Aside from being a source of change, it appears that technology can act as a factor in bringing new ideas or cultures to a traditional society.

\section{Observation and Interview Techniques}

Observation is done by observing directly in the field so that it can see and observe more carefully about the condition of the location of crafters and community-based tourism. In-depth interviews (In-depth Interview) with some informants who have set 12 people.

\section{Documentation Study}

Documentation study, i.e. data collection techniques by taking some documents or records of the past, from the crafters in the village of Tohpati Klungkung and relevant agencies.

\section{Results and Analysis \\ The Adam Smith Free Market Theory}

For the Bali free market, quantitatively it has had a positive impact on various economic sectors such as the number of stands of Multi-National Corporation, job opening, Gross Domestic Product increase, the inclusion of diverse and competitive consumer goods, the availability of international experts and of course the entry New cultures of congenital free markets such as consumerism and lifestyle. However, qualitatively, the impact of the free market on the welfare of sculpture artisans in Tohpati Klungkung Village as envisioned by Adam Smith, seems not to be realized. Indicators indicate that the existence of the Multi-National Corporation is limited to the hiring of cheap labor at the operator level, the swift rush of various products and small industries from various other countries has created thousands of newly unemployed in the real sector, intellectual property rights that make everything more expensive And the most frightening is the large number of emerging import substitution industries that are not the primary industries of domestic demand and pure export orientation. Whereas theoretically, the free market is intended as an economic system to improve the unethical economic system and which is perceived to impede economic growth by providing equal, free and fair business opportunity to all economic actors.

Adam Smith and Hayek also support the ideals of individualism and liberalism in his book "The Road to Serfdom" Hayek affirms support for individualism. By allowing millions of individuals to react to the freely formed market, there will be optimization of capital allocation, human creativity, and labor in a way impossible to imitate by central planning, as good as any planning11. For the neo-liberals, the freedom of the existing individual will not lead to disharmony, on the contrary by the freedom given, individuals can react differently from one another. This means that individual freedom can be a trigger for the formation of a balance that benefits all parties. Hayek Statement:

Pemayun, A., \& Maheswari, A. (2017). Economic Impacts of Craftsman Statue on Community Based Tourism Development. International Journal Of Social Sciences And Humanities (IJSSH), 1(3), 59-73. doi:10.21744/ijssh.v1i3.56 
"The fundamental principle that the ordering of our affairs we should make as much use as possible of spontaneous forces of society, and resort as little as possible to coercion, is capable of an infinite variety of applications"

"The subsequent elaboration of consistent argument in favor of economic freedom was the outcome of a free growth of economic activity which had been the undersigned and unforeseen by-product of political freedom"

Belief in free labor market mechanisms. There is one and only one business social responsibility that is to use all of its resources for activities that serve the accumulated profits. The idea of neoliberalism that is various human relations can be called cultural, political, legal social, psychological, aesthetic, spiritual. But if it should be said in a straightforward manner, the various relationships are guided by the principle of profit and loss transactions that apply in the performance of the market economy. If the unseen curtain opens the main foundation of neoliberalism that is all human relationships both personal and social must be understood in accordance with the concept and economic benchmarks. For the originator of neoliberalism, humans from the beginning are destined to be homo economicus (economic beings). The ontological status of humans as homo economicus has implications on the epistemology aspects that are also economicus. This means that all human problems can only be approached, viewed, understood, or understood through economic concepts and solutions (market system). When choosing a friend then the consideration is whether he is beneficial (bring blessings) or harm. In other words, the ontology and epistemology of homo economicus give the benchmark what a human being is, how he becomes, how he should think and think and ultimately how he should act and relate. Ontology and epistemology gave birth to economicus ethical determinism.

This relates to benchmarks as an evaluation of the various actions and policies of a country's government. Which is the measure of the free market? All government policies should be assessed to what extent free market performance is held. The only judgment is the performance of the free market. Beyond the free market is not an abas as a measure of justice. The notion of neoliberalism believes that the function of the state is no more than a tax collector. That the state seems to still have control and power in determining the direction and policy of development is an illusion. The fact that the state is now unable to control capital inflows, the movement of stocks and currencies with very high fluctuations.

This condition reflects that relying on the state as a growth-driven motor is just as illusory. Neoliberalism also sees that the state has no reason to interfere with and control the market, for it is the market that is the underlying principle of the state and society. The role of the state must be replaced by free market mechanisms, where it becomes the benchmark of all the successes and failures of state policy. The free market is the best solution to solve human, society and country problems. Any rule that curbs the market means supporting the true freedom of man. No free market fails and there is no point in expecting government intervention ${ }^{12}$. While many consider the free market as unethical, immoral and unfair just as voiced by free-market opponents in Third World countries. However, according to the free market advocates, it is a trading system unearthed from the philosophical ethical thought of Adam Smith, a Scottish-born economist, and Philosopher. Through his book Wealth of Nation, Smith emphasizes the need for morality and ethics in a free market that includes justice, equity, and minimal government interference.

Free markets, like other civilizational products, especially those imported from other countries, also have the values contained therein. The values contained in the free market include freedom, equality, justice, equal treatment and of course must be supported by a clear set of laws that contain clear rules of the game and sanctions. The condition of the free market is under a just and democratic government. As well as the role of government should be neutral and able to guarantee the rights and interests of everyone equally and fairly. Failure to adopt the results of thinking and civilization lies not in the value issues brought by the free market from its home country, but rather the unpreparedness of the mentality of society to face the free market. Besides different cultural structures and habits, the work ethic of society also causes the failure of western values can be understood by the people of Bali. In addition to the economic system 
and legal product system, the political system of a particular country greatly affects the effectiveness of free market application in a country especially with the facts in some countries, that most perpetrators of corruption and collusion are the people affiliated both directly and indirectly to political parties certain. The success of the free market is also determined by the level of education and knowledge as well as the national competence of the workforce of a country's population. A country will not be able to open its market freely to another country fairly and profitably if there is still a gap in the quality of education and the skills of free market participants and this applies to the laws of nature. A country with higher human resources and management resources will certainly be able to outwit a country with low resources even if it remains consistent with the value of the free market.

The world today is open and almost borderless world followed by advances in technology and information systems, it's hard to resist the entry of globalization and free markets. It is embarrassing to deny the beauty and enjoyment of the free market. But it is also worth choosing, sorting and making restrictions so that the free market can be taken profit while reducing its negative impacts. It is ridiculous to accept unanimously when values and cultures are different from them. The Balinese culture of communal and mutual help, respect for the elderly and solve everything by deliberation and consensus and most importantly is based on the Supreme Godhead which is certainly very contradictory to individual freedom, equality of rights, and results-oriented which is characteristic of value Western style. Besides, the strength of Indonesia, namely the large population, the abundant natural resources, the area and the strategic location, also have weaknesses, namely the weakness of production technology and systems, less skilled workers, the lack of innovation and the high cost of production Is important to note in the implementation of free market in Indonesia.

This step is also taken by various countries in the free market, they still protect and protect the sector that is considered weak and not yet able to compete with other countries, such as the United States that protect the market of agricultural products or Malaysia that makes the rules of the use of experts or skilled workers domestic as well as the obligation of transfer of technology and science.

Bali is faced with domestic economic problems such as how to drive growth rate, poverty reduction and employment absorption have also been and will face the consequences of facing global trade. Of course, each country has set up infrastructure and market strategy respectively, especially in profit from the trade. A country that has a more comprehensive readiness, then it is he who will be a market and can increase its added value, but otherwise, the State that does not have adequate readiness, then he will not achieve significant market profits. Bali's trade sector, in particular, the creative economy sector has not been able to achieve great benefits because the competitiveness factor of good quality or product packaging has not been adequate for export standards or consumption of the world community.

For that still, a lot of homework that must be in Bali fix in an effort to face the consequences of the free market. ASEAN free market has been in effect since January 1, 2016, with the scheme of agreement from ASEAN countries to establish a free market area in order to improve the economic competitiveness of ASEAN region, with the aim to make ASEAN region as world production base. The free market area began to take effect. With the implementation of a free market agreement between ASEAN and China which began on January 1, 2010. ACTFA (ASEAN China Free Trade Area) in its implementation began to worry about small and medium entrepreneurs (SMEs) in Bali. Balinese small and medium entrepreneurs are worried about the collapse of the domestic industry due to the invasion of Chinese imported products offering a lower price variation. Free markets can not be avoided in a country that embraces an open economy. Given the free market created an acceleration in the growth of the world economy. The World Bank released a report that total elimination of barriers in trade would lift tens of millions of people out of poverty. For Bali, trade liberalization can be a powerful tool for people's poverty reduction. Because with the removal of trade barriers, will make the competition of prices of

Pemayun, A., \& Maheswari, A. (2017). Economic Impacts of Craftsman Statue on Community Based Tourism Development. International Journal Of Social Sciences And Humanities (IJSSH), 1(3), 59-73. doi:10.21744/ijssh.v1i3.56 
similar goods including imported goods that are cheaper will be more competitive. So the purchasing power of society is increasing. This is where the role of sales and marketing strategy of small and medium entrepreneurs, especially sculptor in Desa Tohpati Klungkung, is demanded to be able to create innovations, and cost-efficient production so that the selling price of its production can compete with products from other competitors, especially competitors from outside country. A strategy that must be applied: First, to make efficiency in producing goods, so as to produce competitive product selling price with imported products. Secondly, looking for cheaper alternative raw materials (without reducing the quality), so that production costs can be reduced, so get the selling price of cheaper products. Third, create a better product in quality than other products, at the same price. Fourth, a more aggressive and sustainable marketing strategy, with a regular and efficient distribution pattern. Fifth, provide quality assurance (warranty) to its products (for certain products).

If the above is met, of course, the artisan sculpture in Tohpati Klungkung Village in marketing a product, not only can compete in domestic level, but also can penetrate the regional and international market share. The main problem that should also get the attention and serious handling of the government is the development and strengthening of the cultural industry institutions that are the spearhead of the economic sector. During this position and bargaining crafters and institutional is very weak compared with Malaysia, Thailand, and others. If the institutional culture industry is weak then it will affect the penetration of domestic and foreign markets. In international markets, economic globalization has implications for the increasingly intense competition between business actors, between countries and people not only at the level of comparative advantage but also at the level of politics and diplomacy which are all components of global competitiveness ${ }^{12}$. Goods and services can freely go in and out without any significant barriers, either tariff and quota barriers or non-tariff barriers in the form of policies or other discriminatory aspects ${ }^{13}$. Indonesia's decision to ratify and bind itself to the terms and schemes of world trade (WTO) has brought the consequences of increasingly tough world competition challenges. The concept of fair trade is an ideal condition that may not simply be created from the concept of free markets but requires other non-economic measures, such as domestic institutional reform measures, including the empowerment of creative economic institutions and diplomatic efforts at the international level.

\section{Theory of Cultural Reproduction}

Cultural reproduction is a process of affirmation of cultural identity carried out by immigrants, which in this case affirms the culture of origin. While the process of cultural reproduction is an active process that affirms its existence in social life that requires adaptation for groups with different cultural backgrounds. In other words, cultural reproduction is an affirmation of indigenous culture to a new residence. Cultural reproduction is motivated by changes in the area of residence, social background, cultural background, which in turn will give color to the identity of the group and the identity of ethnicity ${ }^{14}$. Cultural reproduction is the meeting of two different cultures and each other affect each other so that a new culture that embodies elements of the two cultures. One of the contemporary sociological figures, Pierre Bourdieu also put forward his analytical study of cultural reproduction.

Through his concept of habitus and arena and the dialectical relationship between the two, Bourdieu puts his analytical on cultural reproduction. Habitus is a "mental or cognitive structure" by which the sculptor in Tohpati Klungkung village deals with the social world.

These craftsmen are equipped with an internalized scheme that they use to perceive, understand, appreciate, and evaluate the social world. It is through this scheme that the artisans of sculpture in the village of Tohpati Klungkung produce their practice, perceive and evaluate it ${ }^{15}$. In fact, habitus can be thought of as "common sense"16. Habitus is obtained as a result of occupying the position in the social world for a long time. Habitus varies depending on the nature of the statue artist position in Tohpati Klungkung Village in the social world, not all artisans of this statue have the same habitus. However, those who occupy the same position in the social world tend to have the same habitus ${ }^{17}$. While in the dicusology of the sociology of the 
habitus is a combination of various trends so that the actions and attitudes in everyday life become a habit that eventually accepted just like that.

While the arena a kind of a competitive market in which there are various types of capital (economic, social, cultural, symbolic) are used and exploited. There are a number of the semiautonomous arena in the social world (e.g. artistic, religious, college), all of which have their own specific logic and everything to build confidence among the actors about the things they bet on an arena. Bourdieu viewed arena, by definition, as an arena of battle: "Arena is also the scene of the battle"18. If the habitus is in the mind of the actor, then the arena is beyond their mind. In a statement that culture can be a legitimate object of scientific study, more specific terms of culture, analyzed will taste special dishes cooked and tasteful with food made only from the raw material. Appetite, according to Bourdieu is a practice of which gives individuals, as well as other statues craftsman, understanding of the status in the society. Taste brings together those who are in the same position and differentiate them from those with different tastes.

Directly or indirectly, with taste, the artisans of the statue in Tohpati Klungkung Village will classify themselves at the level of certain social classes. Tastes are a good opportunity to state the position of the capturing craftsmen in Tohpati Klungkung Village in the arena and have an impact on the artisans' ability to be in high class to be better able to make their tastes acceptable and to oppose the tastes of those in the lower classes.

Bourdieu connects tastes with one of its main concepts of habitus. More appetites are shaped by placements that form the class's unconscious unity and are deeply entrenched and enduring, the habitus providing an understanding of the meaning of cultural forms such as furniture, clothing, and cuisine.

Bourdieu goes on to make it more interesting: "taste is the governor of the game ...... in which the habitus confirms its proximity to other habitus" (1984a: 243). Although the arena and the habitus are two important things for Bourdieu, the most important is the dialectical relationship between the two; That arenas and habitus give each other meaning. In a more general form, Bourdieu explains: "there is a close relationship between the social position and the disposition of the occupying agent" (1984a: 110). In the life of the sculptor in the village of Tohpati Klungkung, a similar action can derive a different or even contradictory meaning and value if done in different areas, in different configurations, or in opposing sectors in the same arena.

Cultural reproduction is a process of presenting a culture of origin to a culture that was visited or a new environment. The process of cultural reproduction is an active process that lies behind the artisans in Tohpati Klungkung Village to adapt to different cultures. The process of cultural reproduction can occur through social mobility undertaken by a person, from the social mobility of a change in residential areas, cultural background, which eventually became the color for the culture.

The social mobility of a movement or displacement process performed by artisans in the village of Klungkung Tohpati either vertically or horizontally. With the social mobility of the crafters will get new values that are different from the culture they have. Mobility made by craftsmen statue in the village of Klungkung cultivation will lead to changes in some aspects such as changes in the neighborhood, the difference in cultural background. After that happens two possibilities will occur.

First, there is a cultural adaptation of migrants to the culture in which they live, which concerns the adaptation of values and practices of life in general. Local culture becomes a new force that introduces values to immigrants, though not entirely of force. Second, the process of forming an individual identity that can refer to the cultural values of origin. Even able to participate in producing his original culture in a new place. Media transforming cultural reproduction as stated by ${ }^{19}$ that in cultural reproduction, the pressure must always move because it is directed by the effectiveness and demands in order to survive. Example: cultural reproduction conducted by the Net by making the motto "Good people". As if the viewers merged with the topic of the impression. In the media world, presentation techniques outweigh the

Pemayun, A., \& Maheswari, A. (2017). Economic Impacts of Craftsman Statue on Community Based Tourism Development. International Journal Of Social Sciences And Humanities (IJSSH), 1(3), 59-73. doi:10.21744/ijssh.v1i3.56 
content of the messages displayed. So, instead of advertising content that encourages consumption, it becomes effective because it goes through a systematic transition of the realm, signs, messages that equate history with everyday news, events with spectacle, information with advertising. Example: Najwa's eye infotainment on Metro TV seems to exaggerate the sometimes dubious news content, but with a genius show host a nice submission way can convince the audience that the news is true.

Ads based on self-fulfilling props-ry type verification means the art of making things right and confirming that it's true. Ads are not encouraging to learn or understand but invite to hope. Example: Family of Love in TVRI Bali, "Let's build a small family with enough 2 children" meaning if the number of children is limited then the cost of subsequent life is lighter than many children many demands. In the process of the occurrence of cultural reproduction is supported by several internal and external factors, namely: First, increase or decrease the population of artisans statue in the village of Tohpati Klungkung who travel to the city to work because they think that in the city easier to find money and culture higher than the village.

In this case, the process of cultural reproduction occurs when the sculptor in the village Tohpati Klungkung who worked in the city back to the village has brought the city culture that he got from the process of adaptation while working in the city. Second, new discoveries are social and cultural processes that occur in the not-too-distant future.

The new discovery is divided into two discovery: the discovery of new cultural elements, created by sculpture artists in Tohpati Village. An invention that discovery has been acknowledged, accepted, and applied by artisan sculpture in Tohpati Klungkung Village will produce a new culture. Third, conflict is one of the causes of cultural reproduction. Conflicts can occur between the Craftsman statue with other sculpture artisans, sculpture craftsmen with groups, as well as groups with groups. The conflict can lead to cultural reproduction eg men and women have been modified according to their positions and each has different rights and obligations. When a woman feels colonized by a man there will be a feminist movement or a woman demanding justice.

Here we see the process of cultural reproduction or affirmation of the culture of women. ${ }^{20}$. While the cultural reproduction inhibiting factors are: First, the lack of relationships with other sculptor cause they do not know the development that can enrich the culture. Secondly, the statue artist's attitude in the traditional Tohpati Klungkung Village and the exaggeration of past cultures and assume that past traditions have been absolute and irreversible and even reluctant to produce a new culture. ${ }^{21}$

Cultural reproduction is the affirmation of indigenous culture to a new residence. While the process of cultural reproduction is an active process that lies behind someone to adapt to different cultures. The process of cultural reproduction can take place through social mobility by sculpture artists in Tohpati Klungkung village, from the social mobility that changes in the region of residence, cultural background, which eventually became the color for the culture.

Media as a cultural reproduction modifier as stated by 22 that in cultural reproduction, the pressure must always move because it is directed by the effectiveness and demands in order to survive. Example: cultural reproduction conducted by the Net by making the motto "Good people". As if the viewers merged with the topic of the impression. In the media world, presentation techniques outweigh the content of the messages displayed. So, instead of advertising content that encourages consumption, it becomes effective because it goes through a systematic transition of the realm, signs, messages that equate history with everyday news, events with spectacle, information with advertising. Example: Najwa's eye infotainment on Metro TV seems to exaggerate the sometimes dubious news content, but with a genius show host a nice submission way can convince the audience that the news is true. Ads based on selffulfilling prop retype verification means the art of making things right and confirming that it's true. Ads are not encouraging to learn or understand but invite to hope. Example: Family Planning at TVRI Bali Let's build a small family with enough 2 children means the cost of subsequent life is lighter than many children many and many demands. 


\section{Conclusion}

From the above description can be concluded, Firstly, qualitatively, the impact of the free market on the welfare of the sculpture craftsmen in Tohpati Klungkung Village as dreamed by Adam Smith seems not yet to be realized. Indicators indicate that the existence of the MultiNational Corporation is limited to the hiring of cheap labor at the operator level, the swift rush of various products and small industries from various other countries has created thousands of newly unemployed in the real sector, intellectual property rights that make everything more expensive and The most frightening is the large number of emerging import substitution industries that are not the primary industries of domestic demand and pure export orientation. If the unseen curtain opens the main foundation of neoliberalism that is all human relationships both personal and social must be understood in accordance with the concept and economic benchmarks. For the originator of neoliberalism, humans from the beginning are destined to be homo economicus (economic beings). The ontological status of humans as homo economicus has implications on the epistemology aspects that are also economicus.

This means that all human problems can only be approached, viewed, understood, or understood through economic concepts and solutions (market system). If the above can be met, of course, the artisan sculpture in the village of Tohpati Klungkung in marketing a product, not only can compete in the domestic level, but also can penetrate the regional and international market share. The main problem that should also get the attention and serious handling of the government is the development and strengthening of the cultural industry institutions that are the spearhead of the economic sector. During this position and bargaining crafters and institutional is very weak compared with Malaysia, Thailand, and others. If the institutional culture industry is weak then it will affect the penetration of domestic and foreign markets. In international markets, economic globalization has implications for the increasingly intense competition between business people, between countries and people not only at the level of comparative advantage but also at the level of politics and diplomacy that are all components of global competitiveness. The World Bank released a report that total elimination of barriers in trade would lift tens of millions of people out of poverty. For Bali, trade liberalization can be a powerful tool for people's poverty reduction.

Secondly, cultural reproduction is the affirmation of indigenous culture to a new residence. While the process of cultural reproduction is an active process that lies behind someone to adapt to different cultures. The process of cultural reproduction can take place through social mobility by sculpture artists in Tohpati Klungkung village, from the social mobility that changes in the region of residence, cultural background, which eventually became the color for the culture. Media as a cultural reproduction modifier as stated by ${ }^{23}$ that in cultural reproduction, the pressure must always move because it is directed by the effectiveness and demands in order to survive. Example: cultural reproduction conducted by the Net by making the motto "Good people". As if the viewers merged with the topic of the impression. In the media world, presentation techniques outweigh the content of the messages displayed. So, instead of advertising content that encourages consumption, it becomes effective because it goes through a systematic transition of the realm, signs, messages that equate history with everyday news, events with spectacle, information with advertising. Example: Najwa's eye infotainment on Metro TV seems to exaggerate the sometimes dubious news content, but with a genius show host a nice submission way can convince the audience that the news is true. Ads based on selffulfilling prop retype verification means the art of making things right and confirming that it's true. Ads are not encouraging to learn or understand but invite to hope. Example: Family Planning at TVRI Bali Let's build a small family with enough 2 children means the cost of subsequent life is lighter than many children many and many demands. But both cultures can not mix or mingle together. Cultural reproduction can occur because it is supported by several factors including increased and decreased population, new discoveries, conflicts, and globalization. While the inhibiting factor is the statue artist's attitude in the closed Tohpati

Pemayun, A., \& Maheswari, A. (2017). Economic Impacts of Craftsman Statue on Community Based Tourism Development. International Journal Of Social Sciences And Humanities (IJSSH), 1(3), 59-73. doi:10.21744/ijssh.v1i3.56 
Klungkung Village, the fear of shakiness, the slow development of science, and the lack of relationships with other sculpture craftsmen.

\section{Recommendation}

Prioritize the positive value contained in the free market of freedom, equality, justice, equal treatment and must be supported by a clear set of laws that contain clear rules of the game and sanctions. The entry into the free market under a just and democratic government. Cultural reproduction is the migration of indigenous cultures to new residences but still pay attention to the prevailing standards. Media as a cultural reproduction modifier should be in cultural reproduction, the emphasis should not be to move even though directed by the effectiveness and demands in order to survive.

\section{Acknowledgements}

Our deep and sincere gratitude were presented to God for having granted us the ability and the opportunity to complete this paper. We would also like to thank our former lecturers and our friends for their support, their patience, their contribution, and their valuable input, therefore, this article could be completed. We would also thank I Wayan Suryasa as an advisor as well as editor in chief of SS, IJMRA, IJCU, and Skirec who has reviewed and approved this study to be published. 


\section{References}

1. Appadurai, A. (1996). Modernity al large: cultural dimensions of globalization (Vol. 1). U of Minnesota Press.

View in (Google Scholar) (Scopus)

2. Baudrillard, J. (2016). The consumer society: Myths and structures. Sage. View in (Google Scholar) (Scopus)

3. Satori, D. A. Aan komariah, 2012. Metodologi penelitian kualitatif. View in (Google Scholar)

4. Evers, H. D., \& Schrader, H. (1994). The moral economy of trade. Ethnicity and Developing Markets, London.

View in (Google Scholar) (Scopus)

5. Fashri, F. (2007). Penyingkapan Kuasa Simbol Apropriasi Reflektif Pemikiran Pierre Bourdieu. Yogyakarta: Juxtapose. View in (Google Scholar)

6. Ritzer, G., \& Goodman, D. J. (2008). Teori Sosiologi Dari Teori Sosiologi Klasik Sampai Perkembangan Mutakhir Teori Sosial Postmodern. Yogyakarta: Kreasi Wacana. View in (Google Scholar)

7. Adila, I. (2011). Spasialisasi Dalam Ekonomi Politik Komunikasi (Studi Kasus MRA Media). Jurnal Ilmu Komunikasi, 1(01), 93-108. View in (Google Scholar)

8. Pitana, T. S. (2009). Reproduksi Simbolik Arsitektur Tradisional Jawa: Memahami Ruang Hidup Material Manusia Jawa. GEMA TEKNIK Majalah Ilmiah Teknik, 10(2), pp-126. View in (Google Scholar)

9. Bourdieu, P. (2010). Arena Produksi Kultural: Sebuah Kajian Sosiologi Budaya. Terjemahan Yudi Santosa). Yogyakarta: Kreasi Wacana. View in (Google Scholar) (Scopus)

10. Moleong, L. J. (2007). Metodologi Penelitian Kualitatif edisi revisi Bandung: PT Remaja Rosdakarya Offset. ISBN 979-514-051-5.

View in (Google Scholar)

11. Mahar, Harker. 2009. Kosep Praktik Sosial Bourdieu. Yogyakarta: Jalasutra. View in (Google Scholar)

12. Ryan, C., \& Aicken, M. (Eds.). (2005). Indigenous tourism: The commodification and management of culture. Elsevier. View in (Google Scholar) (Scopus)

12. Jolanda, A. P., \& Jolanda, A. P. (2016). Laporan Individu Praktik Pengajaran Lapangan (Ppl) Semester Khusus Tahun 2016/2017. Laporan PPL. View in (Google Scholar)

13. Sugiyono, P. Dr. 2012. Metode Penelitian Kuantitatif, Kualitatif dan R\&D. Cetakan Ke-15. Alfabeta: Bandung.

View in (Google Scholar)

14. Soekanto, S., \& Soemarjan, S. (1969). Sosiologi: suatu pengantar. Jajasan Penerbit Universitas Indonesia.

View in (Google Scholar) (Scopus)

15. Trisna Ari Ayumika, 2012 Arena Reproduksi Kultural. View in (Google)

16. Re-Produksi Budaya | SosiologiBudaya View in (Google)

17. Ghosh, C. (2017). A Study on-Evaluating Marketing Strategies Adopted by Home Appliance for Economic Development in India. International Journal of Social Sciences and Humanities (IJSSH), 1(1), 9-15. View in (Google Scholar)

Pemayun, A., \& Maheswari, A. (2017). Economic Impacts of Craftsman Statue on Community Based Tourism Development. International Journal Of Social Sciences And Humanities (IJSSH), 1(3), 59-73. doi:10.21744/ijssh.v1i3.56 
18. Billaiya, R., Malaiya, S., \& Parihar, K. S. (2017). Impact of Socio Economic Trends on Students in Quality Education System. International Journal of Social Sciences and Humanities (IJSSH), 1(1), 16-20.

View in (Google Scholar)

19. Jain, P. (2017). Cashless System of Colleges in India. International Journal of Social Sciences and Humanities (IJSSH), 1(3), 1-7.

View in (Google Scholar)

20. Amerta, I. M. S. (2017). The Role of Tourism Stakeholders at Jasri Tourism Village Development, Karangasem Regency. International Journal of Social Sciences and Humanities (IJSSH), 1(2), 20-28.

View in (Google Scholar)

21. Larantika, A. A. A. D., Zauhar, S., Makmur, M., \& Setyowati, E. (2017). Collaboration as a Strategy for Poverty Alleviation. International Journal of Social Sciences and Humanities (IJSSH), 1(3), 40-48.

View in (Google Scholar)

22. Adetunji, A. T., Adetunji, A. V., Adeleke, E. O., \& Madubuike, S. C. (2017). Deregulation: The Effect of Market-led Approach to Nigerian Universities Management. International Journal of Social Sciences and Humanities (IJSSH), 1(1), 1-8.

View in (Google Scholar)

23. Cedeño, M. L. D., Arteaga, M. G. D., Pérez, A. V., \& Arteaga, M. L. D. (2017). Regulatory Framework for Renewable Energy Sources in Ecuador Case Study Province of Manabí. International Journal of Social Sciences and Humanities (IJSSH), 1(2), 29-42.

View in (Google Scholar)

24. Basak, A., \& Khanna, K. (2017). A Study on the Selection Criteria of Different Hotels of Delhi NCR in Accordance to the HR Policies and Market Trends. International Journal of Social Sciences and Humanities (IJSSH), 1(1), 27-38.

View in (Google Scholar)

25. Gámez, M. R., Pérez, A. V., Será, A. S., \& Ronquillo, Z. M. (2017). Renewable Energy Sources and Local Development. International Journal of Social Sciences and Humanities (IJSSH), 1(2), 10-19.

View in (Google Scholar)

29. Suparsa, I. N., Mantra, I. B. N., \& Widiastuti, I. A. M. S. (2017). Developing Learning Methods of Indonesian as a Foreign Language. International Journal of Social Sciences and Humanities (IJSSH), 1(2), 51-57.

View in (Google Scholar) 


\section{Biography of Authors}

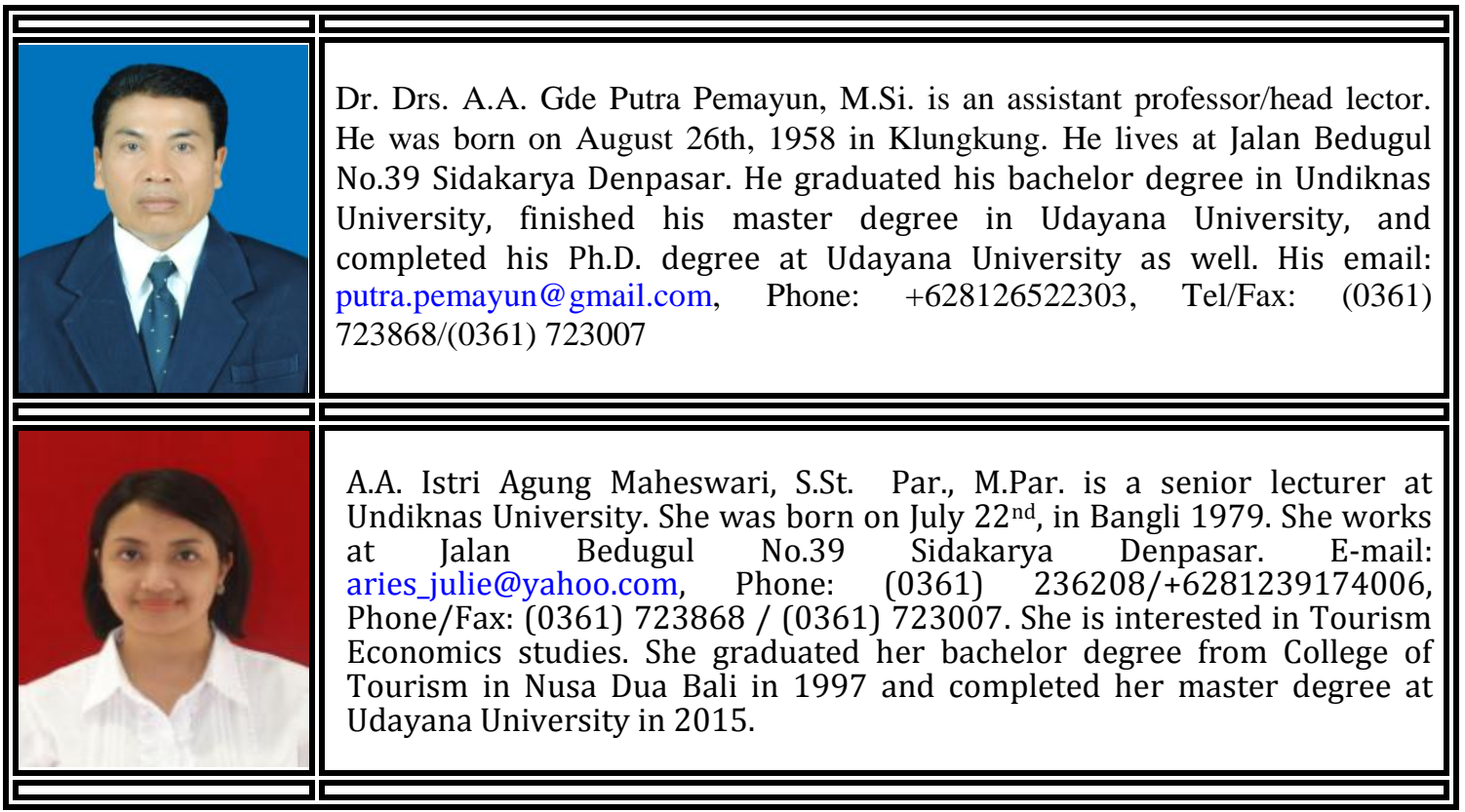

Pemayun, A., \& Maheswari, A. (2017). Economic Impacts of Craftsman Statue on Community Based Tourism Development. International Journal Of Social Sciences And Humanities (IJSSH), 1(3), 59-73. 